\title{
Олег ДЬОМІН,
}

Надзвичайний і Повноважний Посол Украӥни

в Китайській Народній Республіиі

\section{СПІВПРАЦЯ 3 КИТАЄМ: ПОГЛЯД УКРАЇНСЬКОГО ПОСЛА}

Китайська Народна Республіка в останні роки стала одним із світових економічних та політичних лідерів з амбіціями до глобального лідерства, які постійно зростають. Зважаючи на свій нинішній потенціал (політичний, економічний, військовий), зміни на міжнародній арені, Пекін обережно, але невідворотно переходить до реалізації «політики великої держави», нарощуючи свій вплив на світові процеси.

Зовнішня політика України щодо Китаю визначається саме його зміцнілою політичною та економічною вагою у світі, можливістю КНР впливати на глобальному та регіональному рівнях, а також перспективністю китайського ринку для вітчизняної продукції.

КНР визнала Україну 27 грудня 1991 року, а вже за тиждень, 4 січня 1992 року між нашими країнами було встановлено дипломатичні відносини. Наразі на території Китаю діють Посольство України в КНР (Пекін) та генеральні консульства України в містах Шанхай і Гуанчжоу. В нашій державі функціонує Посольство КНР в Україні та Генеральне консульство в Одесі.

Цього року Україна й КНР відзначили 26-ту річницю встановлення дипломатичних відносин. За історичним часовим виміром, цей період може здаватися надто коротким для глибокого аналізу, проте за роки, що минули, безперечно, зроблено значиний крок уперед у розвитку українсько-китайської співпраці та поглиблення дружби, якою традиційно відзначаються взаємини між українським і китайським народами.

Двосторонні відносини між Україною та КНР мають характер стратегічного партнерства. Китай незмінно підтримує суверенітет і територіальну цілісність України. Україна ж залишається неухильно відданою політи- 
ці «одного Китаю». 3 урахуванням змін і реформ в Україні останніх років наразі обидві сторони здійснюють робота, спрямовану на виведення двосторонніх відносин на новий рівень.

Останні державні візити глав держав відбулись у 2011 та 2013 роках, у межах яких було укладено базові документи, які на сучасному етапі визначають та юридично закріплюють підвалини дружби й співробітництва двох держав, досягнення і пріоритети подальшого взаємовигідного розвитку українсько-китайських відносин.

У ході візиту голови КНР до України у червні 2011 року було підписано Спільну декларацію про встановлення та розвиток відносин стратегічного партнерства між Україною та КНР. Державний візит до КНР Президента України у грудні 2013 року було ознаменовано підписанням Договору про дружбу і співробітництво між Україною і КНР, Спільної декларації України і КНР про подальше поглиблення відносин стратегічного партнерства та Програми розвитку відносин стратегічного партнерства між Україною та КНР на 2014-2018 роки. Майбутнє українсько-китайської співпраці, яка набирала обертів, здавалося безхмарним.

Проте 2014 рік вплинув і на відносини України з Китаєм. Імперська політика керівництва Російської Федерації, з якою КНР має особливі зв'язки, військова агресія РФ проти України, спроби Москви дестабілізувати інші європейські держави й об’єднання цивілізованого світу засвідчили тектонічні зрушення у відносинах між державами не лише в Західному світі.

Традиційно обережний у зовнішній політиці Китай обрав позицію «стратегічного вичікування» й не поспішав підтримувати жодну зі сторін конфлікту, обмежившись спостереженням за розвитком ситуації. І хоча в 2014-2017 роках спостерігалося завуальоване гальмування з боку КНР політичної взаємодії на найвищому рівні, Пекін незмінно декларував підтримку суверенітету й територіальної цілісності нашої держави.

Незважаючи на певне «охолодження» двосторонніх відносин у цей період, діалог із Пекіном не переривався. Так, у жовтні 2014 року міністр закордонних справ України П. Клімкін провів зустріч із міністром закордонних справ КНР Ван Ї під час Саміту АСЄМ у Мілані.

У січні 2015 року відбулася зустріч Президента України Петра Порошенка з прем'єром Державної ради КНР Лі Кецяном у межах засідання Всесвітнього економічного форуму (м. Давос).

У січні та грудні 2015 року в Пекіні відбулися політичні консультації на рівні керівництва МЗС двох країн з актуальних питань двосторонніх відносин та з тематики $\mathrm{OOH}$.

Активно використовується й механізм міжпарламентської взаємодії між Верховною Радою України та Всекитайськими зборами народних представників (ВЗНП). У нинішньому складі Верховної Ради України функціонує 


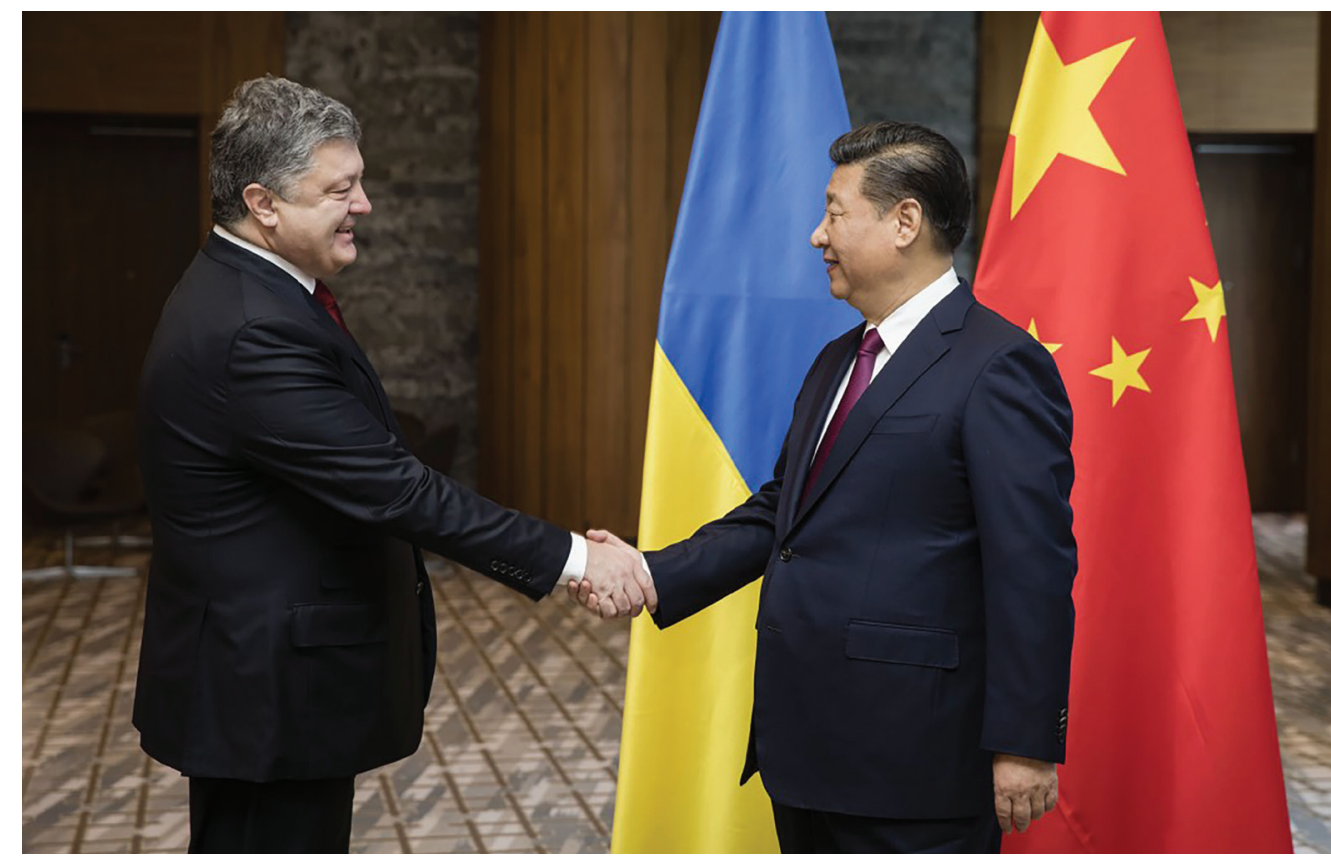

Умежах участі у Всесвітньому економічному форумі в Давосі Президент Петро Порошенко провів зустріч з Головою Китайської Народної Республіки Сі Цзіньпіном

President Petro Poroshenko met with Xi Jinping, President of the People's Republic of China, within the framework of the World Economic Forum in Davos

група з міжпарламентських зв'язків з КНР на чолі з депутатом А. Павелком, одна з найчисленніших за кількістю депутатів у своєму складі. У ВЗНП КНР працює група дружби з Україною на чолі з головою Комітету у закордонних справах пані Фу ̈̈н.

У межах міжпарламентських та міжпартійних контактів упродовж 2015- 2018 років здійснено низку візитів до КНР груп народних депутатів та громадських діячів України. У грудні 2015 року відбувся ознайомчий візит до України делегації Міжнародного відділу ЦК КПК.

Початок відновленню висхідного треку у двосторонніх відносинах поклала зустріч між Президентом України Петром Порошенком та головою КНР Сі Цзіньпіном 1 квітня 2016 року в рамках Вашингтонського саміту з питань ядерної безпеки. Лідери обговорили питання активізації взаємодії між Україною і КНР, а також проведення наступного засідання українсько-китайської міжурядової комісії зі співробітництва.

Наступним кроком став робочий візит до КНР 27-28 квітня 2016 року міністра закордонних справ України П. Клімкіна, під час якого він провів переговори з главою китайського МЗС Ван Ї, зустрічі з іншими посадовцями КНР, а також узяв участь у П’ятій зустрічі міністрів закордонних справ держав-членів та спостерігачів Наради зі взаємодії та заходів довіри в Азії. 


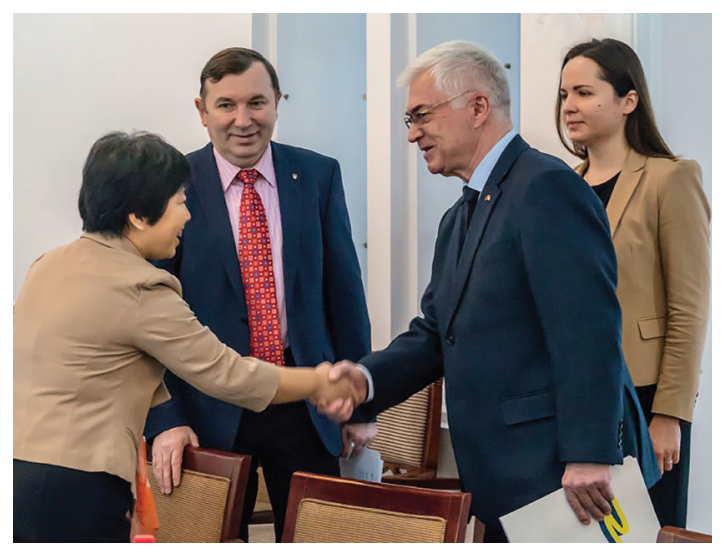

Пан Посол відвідав круглий стіл "Перспективи стратегічного співробітниитва між Украйною та Китаєм". Січень, 2016 р.

Mr. Ambassador visited the round-table discussion "Perspectives of strategic cooperation between Ukraine and China". January 2016
Найбільш знаковим для сучасного етапу українсько-китайських відносин став минулий рік. Так, 17 січня 2017 року в рамках засідання Всесвітнього економічного форуму в Давосі Президент України Петро Порошенко провів зустріч із Головою КНР Сі Цзіньпіном, у ході якої глави двох держав підтвердили взаємну зацікавленість в активізації політичного діалогу на найвищому рівні й поглибленні економічної співпраці між Україною і КНР. Було досягнуто домовленості щодо проведення до кінця 2017 року чергового, Третього засідання Українсько-китайської

Міжурядової комісії зі співробітництва та участі делегації України у міжнародному форумі ініціативи «Один пояс, один шлях» (Пекін, травень 2017 року). Важливе значення мало й підтвердження Сі Цзіньпіном незмінності підтримки Китаєм територіальної цілісності й суверенітету України.

18 вересня 2017 року під час 72-ї сесії Генасамблеї ООН у Нью-Йорку відбулася зустріч глав МЗС України Павла. Клімкіна та КНР Ван Ї, у центрі якої була взаємодія двох країн у провідних міжнародних організаціях.

5 грудня 2017 року в Києві, в рамках Третього засідання Комісії зі співробітництва між урядами двох країн, відбулись окремі зустрічі Президента України Петра Порошенка, прем'єр-міністра Володимира Гройсмана та першого віце-прем'єр-міністра, міністра економічного розвитку і торгівлі України Степана Кубіва з главою китайської делегації, заступником глави Уряду КНР Ма Каєм. Проведені зустрічі дали нагоду досягти конкретних домовленостей щодо реалізації масштабних спільних проектів.

Провідну роль Угоди про стратегічне партнерство між Україною і Китаєм відіграє економічний складник.

Китай посідає перше місце серед торговельних партнерів України в Азійсько-Тихоокеанському регіоні і залишатиметься таким і надалі. Тому сьогодні, плануючи розвиток торговельно-економічних відносин між Україною та Китаєм, важливо врахувати тенденцій зовнішньої та внутрішньої політики самого Китаю, адже, наприклад, питання зміцнення власної продовольчої безпеки та активного впровадження будівництва «інноваційної держави» дозволяє максимально використовувати наявний в Україні потенціал. 
У цьому контексті Україна має величезні можливості та сприятливі умови для того, щоби збільшити свій експорт, компенсувати втрати бізнесу від закриття Росією своїх ринків для нас, створити умови для значного нарощування обсягів іноземних інвестицій, збудувати сучасну інфраструктуру, яка створюватиме реальне підгрунтя для розвитку бізнесу.

Цьому процесові сприяють міжурядові домовленості, зокрема щодо спільної участі країн у будівництві економічного поясу в рамках ініціативи «Один пояс, один шлях», та ініціативність приватних ділових кіл, які мають плани розширення географії свого бізнесу через приватні капіталовкладень.

У цьому контексті, для забезпечення подальшого розвитку українсько-китайської економічної співпраці наприкінці 2017 року на засіданнях Підкомісії з питань ТЕС у Пекіні та Комісії зі співробітництва між урядами України і Китаю у Києві, що відбулась під час візиту віце-прем'єра Держради КНР Ма Кая до України, було прийнято важливі рішення.

У підсумкових документах цих міжурядових діалогів Україна і Китай визначили пріоритетні напрями співпраці на найближчі 2-3 роки, у відповідні проекти яких китайська сторона планує вкласти до 7 млрд дол. США.

Найбільший за всі часи товарообіг між Україною та КНР склав майже 10 млрд дол. США, у 2017 році - 7,7 млрд дол. США. Останні три роки ми спостерігаємо як змінюється структура українського експорту до Китаю. Частка сільгосппродукціі, переробки і харчових товарів вже перевищує його сировинну частину: торік обсяг торгівлі аграрною та продовольчою продукцією з Китаєм склав майже мільярд доларів США (половина всього українського експорту), руди - трохи більше 700 мільйонів.

Україна вже кілька років експортує в Китай кукурудзу та ячмінь, які користуються попитом на китайському ринку, а 95\% імпортованої в КНР соняшникової олії $\epsilon$ саме українська. За останні два роки українським регуляторам продовольчого сектору та Посольству вдалося на додаток до зазначеної продукції отримати від Китаю дозволи на експорт молочної продукції, яловичини, соняшникового шроту та бурякового жому, у найближчий перспективі - кормові добавки, борошно, мед, риба, плодово-ягідна продукція.

Важливим складником економічної співпраці є інвестиційне партнерство. Протягом останніх 3 років паралельно з реалізацією проектів національного рівня розвивалось інвестиційне співробітництво між приватними структурами України і Китаю. Так, китайська корпорація «СОFСО Agri» у 2016 році запустила в експлуатацію перевантажувальний комплекс зернових і олійних культур річною потужністю 2,5 млн тонн в Миколаївському морському торговельному порту. Китайській компанії CNBM в Україні належить десять найбільших сонячних електростанцій, розташо- 


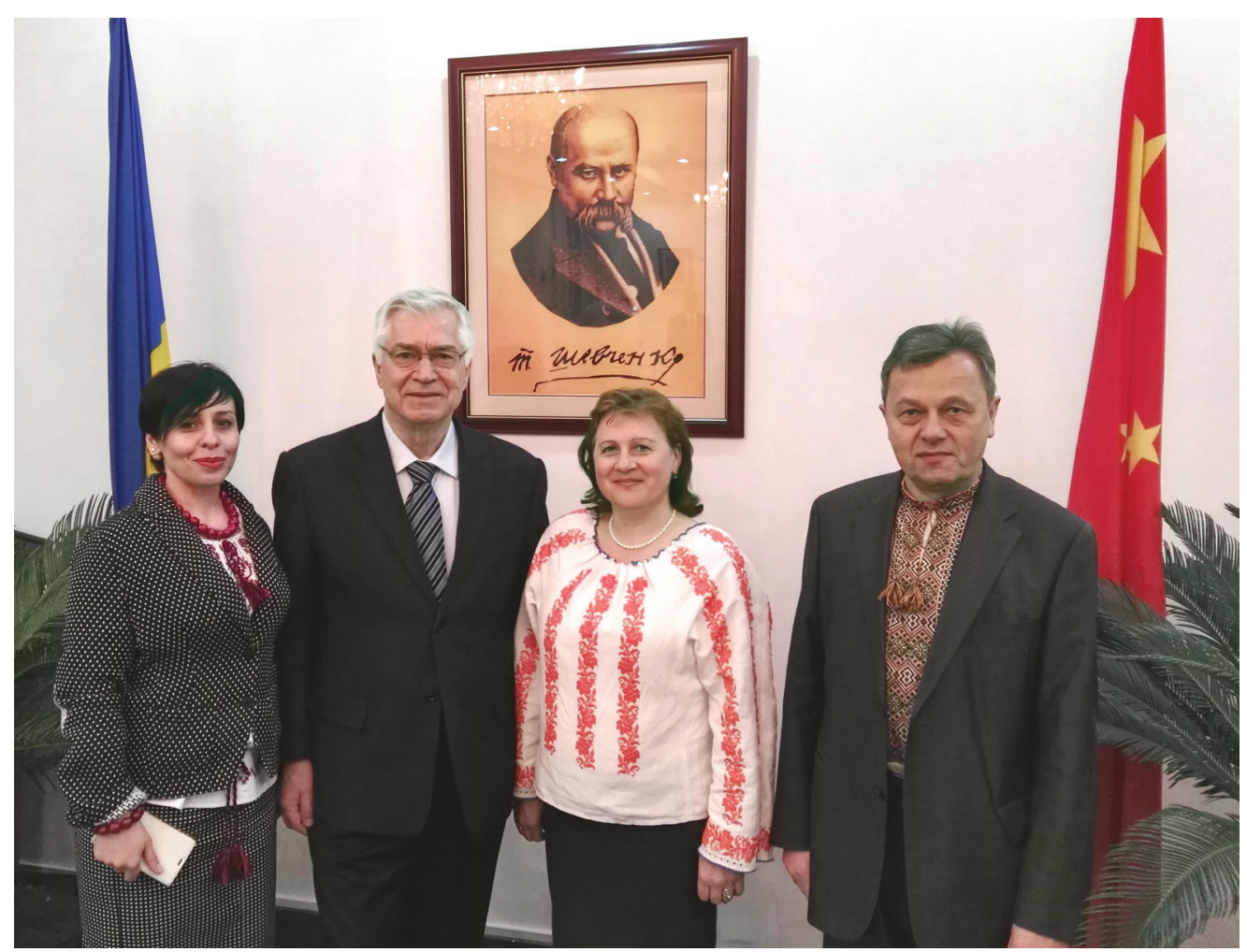

Учасники презентації нового видання поезій Тараса Шевченка китайською мовою. Зліва направо: Валентина Рождественська, Олег Дьомін, Галина Івашків, Василь Івашків

Participants of presentation of new edition of Taras Shevchenko poetry in Chinese. Left to right: Valentyna Rozhdestvenska, Oleh Diomin, Halyna Ivashkiv, Vasyl Ivashkiv

ваних у Миколаївській та Одеській областях (їх сумарна потужність є тотожною половині всіх українських сонячних електростанцій на сьогодні). Український телекомунікаційний оператор «Просат» разом із китайською компанією «XinweiGroup» (одна із провідних телекомунікаційних компаній світу) створює мережу мобільного широкосмугового мультимедійного зв’язку 4 покоління національного масштабу. У Китаї, в місті Чунцін, будують завод, який виготовлятиме авіаційні двигуни за українськими ліцензіями і за безпосередньої участі всесвітньо відомої компанії «Мотор Січ». Торік найбільша товарна біржа Китаю BohaiCommodity Exchange Co. Ltd. (BОСЕ) придбала 99,9\% Українського банку реконструкції і розвитку. Україна і Китай вже визначились із перспективними напрямами інвестиційної взаємодії. Насамперед - це використання китайського капіталу для організації виробничих потужностей в Україні - від переробки аграрної продукції та легкої промисловості до енергетичного машинобудування і збірки електромобілів. Розвитку цього напряму також сприятиме і доступ України на ринок ЄС. 
Інвестиції китайських корпорацій впливатимуть на розвиток ринку аграрної продукції в Україні - від первинної продукції рослинництва й тваринництва до готових продуктів харчування - екологічно чистих та високої якості, які останнім часом користуються значним попитом серед китайських споживачів.

Важливими напрямами є інвестування в інфраструктуру України, яка забезпечує розвиток економіки взагалі, співпрацю в науці та розробці нових технологій, що завжди було сильною стороною України і привабливим для наших китайських партнерів, та співробітництво в галузі альтернативної енергетики, спрямоване насамперед на забезпечення енергетичної безпеки України.

Загалом, на сучасному етапі Україна, як потенціальний реципієнт китайського капіталу, має орієнтуватися на принципи, за якими Китай вкладає свої інвестиції за кордон, зокрема в Європу. Відповідно до ефективного використання наявного ресурсу капіталу, успішної реалізації пілотних проектів без ознак корупційних схем, ми можемо претендувати на розширення механізмів інвестиційної співпраці, пом'якшення китайської державної політики кредитування та інвестування, внесення України до перспективних інвестиційних планів та програм, зокрема з розбудови інфраструктури, яка зв’язує Китай з Європою.

Культурно-гуманітарна сфера посідає одне з чільних напрямів співпраці між Україною та Китаєм. Важливим механізмом контролю й регулювання $€$ українсько-китайська Підкомісія з питань співробітництва у сфері культури, четверте засідання якої відбулося в Пекіні у листопаді 2017 р. Під час заходу сторони не тільки обговорили нові тенденції розвитку взаємодії на цьому напрямі, а й досягли низки домовленостей щодо істотного iï розширення, узгодили проект Програми культурного співробітництва між Міністерством культури України та Міністерством культури КНР на 2018-2022 роки, підписану 5 грудня 2017 р. під час Третього засідання Міжурядової комісії.

Важливу роль у розвитку співробітництва у сфері культури відіграють дипломатичні представництва двох країн. Прикладом цього $є$ результати активної співпраці Посольства України в КНР з культурно-мистецькими установами та неурядовими організаціями Китаю (Центральна академія образотворчого мистецтва, Пекінська народна асоціація дружби із закордоном, художня академія «Лі Кежань», Спілка художників Китаю, Китайсько-український центр культурних обмінів тощо). За участі цих організацій протягом минулого року в Україні й КНР було організовано близько 30 спільних мистецьких заходів. Наприклад, у Національному музейному комплексі Гугун було проведено Українсько-китайську художню виставку «Один пояс, один шлях. Зустріч на Дніпрі», співорганізатором якої з української сторони була Національна академія образотворчого мистецтва України. 
Однією з найпомітніших тенденцій культурної взаємодії між Україною та Китаєм є зростання інтересу до українського кіно- і телевиробництва. Як приклад, у вересні 2017 р. було підписано Угоду про спільне українсько-китайське кіновиробництво між українською компанією Film.ua та китайською China International Art Business Alliance.

Помітну роль у розширенні співпраці відіграє «Український дім» у Пекіні, який став майданчиком для співпраці між нашими країнами, осередком тематичних зустрічей, презентацій, семінарів за участі української громади та студентства, присвячених історії, традиціям, культурі нашої країни.

У Китаї активно розвиваються українознавчі студії. На додаток до центрів україністики з вивченням української мови у п’яти ВНЗ Пекіна, Шанхая, Даляня, Тяньцзіня й Уханя, за активної допомоги Посольства розпочали роботу центри українських досліджень у Професійно-технічному інституті провінції Шеньсі (м. Сіань) та в Сіаньському університеті іноземних мов, триває робота з розвитку такого центру в Харбіні.

Загалом розширення напрямів культурно-гуманітарної співпраці між Україною й КНР, активізація відповідних контактів надають значні сприятливі можливості для поглиблення практичної співпраці, зміцнення довіри та взаєморозуміння між нашими народами. 